$\begin{array}{llllllllll}\mathbf{M} & \mathbf{A} & \mathbf{T} & \mathbf{E} & \mathbf{R} & \mathbf{I} & \mathbf{A} & \mathbf{L} & \mathbf{Y}\end{array}$

STUDIA POLONIJNE

T. 39. LUBLIN 2018

DOI: http://dx.doi.org/10.18290/sp.2018.14

EWA JASZEWSKA

\title{
DRUGIE ZEBRANIE KSIĘŻY POLSKIEJ MISJI KATOLICKIEJ WE FRANCJI
}

W 1921 roku według oficjalnych danych przebywało we Francji 45 tys. obywateli polskich, pięć lat później było ich już 309 tys. ${ }^{1}$ Największą możliwość zamanifestowania wówczas przez naszych rodaków więzi z ojczyzną stwarzała struktura organizacyjna polskiej opieki religijnej, tzn. sieć stałych i dojazdowych placówek duszpasterskich. Ich powstanie i rozwój był głównie zasługą samych wychodźców, którzy podejmując pracę domagali się od pracodawców kościoła i szkoły ${ }^{2}$. Dzięki współpracy Episkopatu Polski i Francji, związku pracodawców francuskich w głównych skupiskach emigrantów polskich powstała trwała struktura duszpasterstwa polskiego. 13 maja 1922 roku powołano do życia Misję Polską Katolicką we Francji, która obejmowała swoim zasięgiem cały $\mathrm{kraj}^{3}$. Na podstawie utworzonych ośrodków duszpasterskich kapłani polscy, którzy byli formalnie wikariuszami francuskich proboszczów, podjęli posługę duszpasterską wśród rodaków. Działania te inspirował i koordynował ks. Wilhelm Szymbor ${ }^{4}$, ówczesny rektor Polskiej Misji Katolickiej (PMK).

Mgr Ewa JASZEwSKa - doktorantka w Instytucie Historii i Politologii Akademii Pomorskiej w Słupsku; e-mail: jaszewska@poczta.onet.pl

${ }^{1}$ J. Ponty, Les aumoniers polonais en milieu ouvrier immigre dans la France de l'entre deux guerres, w: Les contacts religieux franco-polonais du moyen age a nos jours. Relations, influences, images d'un pays vu par l'autre. Colloque international organisé par le C.N.R.S., GRECO nr 2. Histoire religieuse moderne et contemporaine et le Centre Interdiscipinaire d'Etudes des Religions de l'Université de Lille III. Lille 5-7 octobre 1981, Paris 1985, s. 568-575.

${ }^{2}$ R. Dzwonkowski, Życie religijne Polonii francuskiej w latach 1920-1986 jako wyraz więzi z krajem pochodzenia, „Studia Polonijne” 15(1993), s. 35.

3 J. KLechta, Najstarsza w świecie. Polska Misja Katolicka we Francji 1836-2006, Paryż 2006; Materiaty do dziejów Polskiej Misji Katolickiej we Francji, z. II: Księża polscy w duszpasterstwie poludniowej Francji 1922-1929, oprac. O.B. Panek OC, Paris 1993, s. 4-13.

${ }^{4}$ Wilhelm Szymbor - kapłan Zgromadzenia Księży Misjonarzy św. Wincentego a Paulo CM (lazarysta). Urodził się 16 października 1879 w Niwce k. Będzina. Studia filozoficzne i teologiczne odbył na Kleparzu i na Stradomiu. Święcenia kapłańskie przyjął 5 lipca 1903. W 1. 1903-1908 mieszkał w domu kleparskim i pracował w grupie rekolekcyjno-misyjnej. W 1. 1908-1911 był dyrektorem 
Od samego początku duszpasterze polscy wywierali zasadniczy wpływ na organizowanie się wychodźstwa polskiego. Na zasadzie porozumienia z dyrekcjami kopalń w ośrodkach zamieszkałych przez Polaków, kapłani inspirowali lokalne polskie stowarzyszenia do obrony społecznych interesów emigracji i umacniania polskości ${ }^{5}$. Podejmowane działania były o tyle istotne, że - jak sygnalizowano na łamach „Polaka we Francji” - zauważalny był „brak wyraźnej polityki polskiej emigracyjnej, oraz zakusy niektórych czynników we Francji, zdążające do rozwiązania naszych stowarzyszeń polskich, zmuszania robotników polskich do organizowania się w socjalistycznych i komunistycznych syndykatach francuskich"6.

Wszystkim tym wyzwaniom usiłowała sprostać PMK pod kierownictwem ks. rektora. Zorganizowany kolejny zjazd duchowieństwa uwrażliwiał kapłanów na bieżące potrzeby rodaków, domagających się bliższego kontaktu z duszpasterzem, umożliwiał wymianę doświadczeń duszpasterskich. Skalę tych wyzwań egzemplifikuje m.in. dokument: Protokół z drugiego Zebrania Księży Polskich, pracujących wśród wychodźstwa polskiego we Francji, odbytego dnia 15 listopada 1923 w lokalu Misji Polskiej w Paryżu.

Kopia dokumentu znajduje się w Archiwum Polskiej Misji Katolickiej we Francji. G. III. 2. Zjazdy duszpasterskie, sympozja, kursy dokształcające, 1923-1956; G. III. 2. 1. Zjazdy duszpasterzy Misji. N-ry 1-11. Protokół z drugiego Zebrania Księży Polskich,

Małego Seminarium w Krakowie na Nowej Wsi; następnie wrócił do pracy w grupie misyjnej. Do pracy rekolekcyjno-misyjnej włączył (1912-1914) regularne wyjazdy do skupisk robotniczych emigrantów polskich na terenie Niemiec, Danii i Szwecji. Na prośbę prymasa kard. Edmunda Dalbora 10 maja 1922 podjął się reorganizacji duszpasterstwa polonijnego we Francji. Zamieszkał w Paryżu i podjął obowiązki rektora Polskiej Misji Katolickiej we Francji. Dokonał reorganizacji duszpasterstwa polonijnego, doprowadził do zjednoczenia rożnych organizacji religijnych w Związek Polskich Towarzystw Katolickich. Pod koniec lipca 1928 złożył rezygnację ze stanowiska rektora Misji. Pozostawił 30 placówek duszpasterstwa polskiego zorganizowanych w czterech dekanatach: paryskim, północnym, wschodnim i zachodnim. W duszpasterstwie polonijnym pracował do czerwca 1929. Na początku lipca tegoż roku rozpoczął pracę rekolekcyjno-misyjną w ośrodkach duszpasterskich w Brazylii. Od sierpnia 1931 pełnił obowiązki superiora domu oraz rektora Instytutu Teologicznego w Krakowie na Stradomiu. 1 października 1935 został rektorem Śląskiego Seminarium Duchownego w Krakowie oraz superiorem domu Zgromadzenia. We wrześniu 1939, po likwidacji seminarium przez władze okupacyjne, zamieszkał na Stradomiu. 11 sierpnia 1944 został aresztowany przez Niemców i osadzony w więzieniu przy Montelupich w Krakowie, a następnie w obozach koncentracyjnych: od 1 października 1944 we Flossenburgu, od 11 listopada - w Mulsen, od 23 grudnia 1944 do 29 kwietnia 1945 - w Dachau. Po wyzwoleniu z obozu, przez kilka miesięcy prowadził działalność duszpasterską wśród rodaków w rejonie Paryża. W 1946 powrócił do kraju i został superiorem domu oraz rektorem Instytutu Teologicznego na Stradomiu. Zmarł 9 grudnia 1946. Misjonarze św. Wincentego a Paulo $w$ Polsce (1651-2001), t. II-1: Biografie, red. J. Dukała CM, Kraków 2001, s. 484-490; Materiały do dziejów Polskiej Misji Katolickiej we Francji, z. I: Księża polscy w duszpasterstwie okręgu paryskiego 1922-1929, oprac. O.B. Panek OC, Paris 1992, s. 111-113; ks. J. SzYMaŃsKi, Duszpasterze Polonii i Polaków za granica. Stownik biograficzny, t. I, Lublin 2010, s. 142-144.

${ }^{5}$ H. ŁubieŃski, Przed Zjazdem Duchowieństwa polskiego w Paryżu, „Polak we Francji” 14 XII 1924, s. 2.

${ }^{6}$ Emigracja polska we Francji zagrożona, „Polak we Francji” 23 XI 1924, s. 9. 
pracujących wśród wychodźstwa polskiego we Francji, odbytego dnia 15 listopada 1923 w lokalu Misji Polskiej w Paryżu, k. 9.

Dokument oryginalny w formie maszynopisu przechowywany jest w Archiwum Archidiecezjalnym w Gnieźnie, Archiwum Prymasa Polski, Akta Protektora Wychodźstwa Polskiego, Francja, Dział III/14a, Protokół z drugiego Zebrania Księży Polskich, pracujących wśród wychodźstwa polskiego we Francji, odbytego dnia 15 listopada 1923 w lokalu Misji Polskiej w Paryżu, k. 9. [strona pierwsza i druga opatrzona okrągłą pieczęcią Archiwum Archidiecezjalnego w Gnieźnie].

\section{PROTOKÓŁ}

z drugiego zebrania Księży Polskich, pracujących wśród wychodźstwa polskiego we Francji, odbytego dnia 15 listopada 1923 w lokalu Misji Polskiej w Paryżu?

Obecni: rektor Misji Polskiej ks. [Wilhelm] Szymbor; księża prałaci [Teodor] Ta$\operatorname{czak}^{8}$ i [Piotr] Trocki-[Łodzia]'; księża: ks. [Mieczysław] Gieszczykiewicz ${ }^{10}$, [Augustyn]

${ }^{7}$ Zachowano oryginalną pisownię i styl.

${ }^{8}$ TeOdOR TACZAK - kapłan archidiecezji gnieźnieńskiej. Urodził się 16 października 1878 w Mieszkowie k. Jarocina. Studiował w Arcybiskupim Seminarium Duchownym w Gnieźnie i Poznaniu. Święcenia kapłańskie przyjął 10 marca 1901. Studia kontynuował na uniwersytecie w Monasterze, gdzie w 1903 uzyskał doktorat. Podczas studiów angażował się w posługę duszpasterską wśród Polaków w Saksonii (Bochum, Paderborn). Po powrocie pełnił obowiązki mansjonarza przy kościele św. Wojciecha w Poznaniu. Od 1908 był profesorem w Seminarium Duchownym w Gnieźnie. W 1909 został kanonikiem przy kolegiacie św. Jerzego w Gnieźnie. Od 1911 był redaktorem wychodzących w Poznaniu „Wiadomości Apologetycznych”. W 1914 został wikariuszem generalnym archidiecezji gnieźnieńskiej, a od 1916 - prezesem Sądu Duchownego w Gnieźnie i także wiceprezesem Wydziału Teologicznego Poznańskiego Towarzystwa Przyjaciół Nauk. W 1920 został tajnym szambelanem papieskim. Od 11 listopada 1921 podjął posługę duszpasterską wśród rodaków we Francji (Alzacja Lotaryngia). 29 marca 1924 prosił księdza prymasa o zwolnienie z pracy i wyznaczenie odpowiedniego stanowiska w diecezji. W sierpniu 1925 wyjechał do Polski. 18 listopada 1925 został proboszczem w parafii MB Wniebowziętej w Śremie. W latach 1928-1929 był redaktorem tygodnika parafialnego „Gość Niedzielny” w Śremie. Od grudnia 1930 podjął obowiązki proboszcza w parafii św. Marcina w Poznaniu. Tam założył Parafialną Akcję Katolicką. Zbudował Dom Parafialny przy ul. Św. Marcina (1932). 11 września 1939 został aresztowany przez Niemców jako zakładnik i uwięziony w Sali Złotej oraz Sali Biblioteki Starego Ratusza. 30 października 1939 zwolniony i zmuszony do wyjazdu do Generalnego Gubernatorstwa. Zmarł nagle na ulicy w Warszawie 22 czerwca 1941. Materiaty do dziejów Polskiej Misji Katolickiej we Francji, z. III: Księża polscy w duszpasterstwie Dekanatu Wschodniego 1922-1929, oprac. O.B. Panek OC, Paris 1992, s. 105-108; М. Снамот, Taczak Teodor (1878-1941), w: Stownik Biograficzny Katolicyzmu Społecznego w Polsce, t. III: R-Ż, Lublin 1995, s. 130; ks. M. WolniEwicz, Taczak T., w: Stownik polskich teologów katolickich 1918-1981, red. ks. L. Grzebień SJ, t. VII, Warszawa 1983, s. 305; ks. J. SzYmański Duszpasterze Polonii i Polaków za granica. Stownik biograficzny, t. II, Lublin 2011, s. 177-178.

${ }_{9}$ Piotr Trocki-ŁodzIA - studiował na KUL-u; od 1921 przebywał we Francji: Beaulieu, Marseille, Mericourt, Nice, Nimes, Noeux-Les-Mines, Roche-la-Molière, Noeux-les-Mines; 1925-1928 studiował we Fryburgu Szwajcarskim, po powrocie był katechetą w Wilnie, 1938/1940 - prof. na Uniw. Stefana Batorego, 1941-1943 aresztowany, po „repatriacji” pracował w seminarium w Białymstoku i Akademii Teologii Katolickiej w Warszawie. Materiały, z. 1, s. 113-114; M. BRudzisz, Pierwsze zebranie księży Polskiej Misji Katolickiej we Francji, „Studia Polonijne” 33(2012), s. 145. 
Jakubisiak $^{11}$, [Grzegorz] Janiewski ${ }^{12},\left[\right.$ Franciszek] Krupa ${ }^{13}$, [August] Lurat ${ }^{14},[$ Ferdynand $]$

10 MieCZySŁaw GiesZCZYKIEwiCZ - kapłan archidiecezji krakowskiej; od 30 października 1922 kapłan Zgromadzenia Księży Misjonarzy św. Wincentego a Paulo CM (lazarysta). Urodził się 1 stycznia 1898 w Krakowie. Święcenia kapłańskie przyjął 20 marca 1921. Obowiązki duszpasterskie we Francji podjął w 1923 w Paryżu. Zmarł 19 czerwca 1934 w Krakowie. Materiaty, z. 1, s. 27; ks. W. UmiŃski CM, Polska prowincja Zgromadzenia Księży Misjonarzy w latach 1918-1939, Kraków 2009, s. 248-249, 275.

${ }^{11}$ AuguSTYN JAKUBISIAK - kapłan archidiecezji warszawskiej. Urodził się 28 maja $1884 \mathrm{w}$ Warszawie. Po ukończeniu gimnazjum w Warszawie podjął studia filozoficzno-teologiczne w Metropolitalnym Wyższym Seminarium Duchownym, gdzie w 1906 przyjął święcenia kapłańskie. Przez cztery lata był wikariuszem. Od 1910 studiował na Uniwersytecie Katolickim i na Sorbonie w Paryżu. Od 1915 władze francuskie powierzyły mu funkcję kapelana wszystkich jeńców-Polaków we Francji. Wydawał dla nich pismo „Jeniec Polski”. Następnie został kapelanem w armii J. Hallera i razem z armią przybył do kraju. W Warszawie pełnił obowiązki kapelana Francuskiej Misji Wojskowej. W 1920 powrócił do Paryża i podjął obowiązki duszpasterskie. Od 1926 był kapelanem więźniów Polaków w więzieniach departamentu Sekwany. Jednocześnie prowadził badania naukowe z zakresu filozofii. Z chwilą wyzwolenia Francji, w 1944 powrócił do Paryża i został delegatem Ministerstwa Wyznań Religijnych i Oświecenia Publicznego emigracyjnego rządu londyńskiego. Zmarł 23 listopada 1945 w Paryżu. Materiały, z. I, s. 37-38; P.J. BADURA, Jakubisiak Augustyn (1884-1945), w: Słownik polskich teologów katolickich, t. V, s. 563-564.

${ }^{12}$ Grzegorz JANIEwSKI - kapłan Zgromadzenia Księży Misjonarzy św. Wincentego a Paulo CM (lazarysta). Urodził się 4 maja 1889 w Gołogórach k. Lwowa. 7 lutego 1910 został przyjęty do zgromadzenia. Studia filozoficzne i teologiczne odbył na Stradomiu. Święcenia kapłańskie przyjął 24 czerwca 1915. Przez 2 lat studiował historię i język starosłowiański na uniwersytecie lwowskim. W 1. 1917-1919 był kapelanem wojsk polskich na Węgrzech. Od 1919 dyrektorem Seminarium Duchownego. W 1923 podjął posługę duszpasterską we Francji. Posługę duszpasterską wśród rodaków pełnił w: Cagniac, Carmaux, Gagnieres-Les-Mines, Le Creusot, Le Gua Par Aubin, Montceau-Les-Mines, Paris. Od 1931 do 1956 był superiorem Domu Misyjnego w Krakowie. Zmarł 25 października 1985 w Krakowie. Materiały, z. I, s. 39-40; W. UMIŃski, Polska prowincja Zgromadzenia Księży Misjonarzy, s. 276.

${ }^{13}$ FranCISZEK KRUPA - kapłan diecezji włocławskiej. Urodził się 19 stycznia 1893 w Ręcznie, k. Piotrkowa Trybunalskiego. Syn Antoniego i Kazimiery z d. Nowicka (w 1931 zmienił nazwisko na Korszyński). Studia filozoficzno-teologiczne ukończył w Wyższym Seminarium Duchownym we Włocławku. 25 lipca 1915 z rąk bpa Stanisława Zdzitowieckiego przyjął święcenia kapłańskie. W 1916 wyjechał do Fryburga w Szwajcarii. Po powrocie do kraju był wikariuszem i prefektem w szkołach powszechnych we Włocławku. W 1. 1920-1922 był dyrektorem Niższego Seminarium Duchownego we Włocławku i jednocześnie profesorem w Wyższym Seminarium Duchownym. Od 25 września 1922 w Paryżu pełnił funkcję kapelana w zakładzie Sióstr Miłosierdzia św. Kazimierza. Po powrocie do Włocławka 20 października 1924, kontynuował pracę w Wyższym Seminarium Duchownym. W 1925 został ojcem duchownym seminarium. W lipcu 1939 został rektorem Wyższego Seminarium Duchownego we Włocławku. 7 listopada 1939 wraz z innymi wykładowcami Seminarium i klerykami został aresztowany przez Niemców i osadzony w miejscowym więzieniu. 25 kwietnia 1941 został wywieziony do obozu koncentracyjnego w Dachau (nr obozowy 24546). Po wyzwoleniu udał się z klerykami włocławskimi do Paryża. Do kraju powrócił 2 maja 1946 i objął na nowo stanowisko rektora seminarium. W dniu powrotu do kraju otrzymał wiadomość o ustanowieniu go biskupem tytularnym Orisy w Syrii i biskupem pomocniczym w diecezji włocławskiej. Od 16 marca 1951 (do 25 października 1953) zarządzał diecezją włocławską jako wikariusz generalny bp. Antoniego Pawłowskiego. Zmarł w szpitalu w Otwocku 3 listopada 1962. Korszyński Franciszek, 
Machay $^{15}$, [Szczepan] Misiak ${ }^{16}$, [Jan] Sadowski ${ }^{17}$, [Antoni] Servignat ${ }^{18}$, [Władysław]

w: Włocławski słownik biograficzny, red. S. Kunikowski, t. I, Włocławek 2004, s. 72-73; W. KuJAwsKI, Sufragani włocławscy w XX wieku, w: W Panu złożyłem nadzieję. Księga pamiatkowa ku czci Bpa Czesława Lewandowskiego w 80. rocznice urodzin, Włocławek 2002, s. 153-155.

14 August LuRAT - kapłan archidiecezji paryskiej, znający język polski. W 1. 1910-1925 szczególną opieką otaczał Polaków przebywających w Paryżu, w barakach przy bulwarze Jourdan 48 . Materiaty, z. I, s. 62.

15 FerdynAND MachaY - kapłan archidiecezji krakowskiej. Urodził się 4 maja 1889 w Jabłonce na Orawie. Szkołę średnią ukończył w Trzcianie i Bratysławie. Studia filozoficzno-teologiczne odbył w Spišskiej Kapitule i na Wydziale Teologicznym Uniwersytetu w Budapeszcie. W 1912 przyjął święcenia kapłańskie, po czym sprawował funkcję wikariusza w parafiach w Zázrivej i w Ružomberku. Jednocześnie w 1. 1913-1914 był współpracownikiem „Gazety Podhalańskiej”. Podczas I wojny światowej był kapelanem armii austro-węgierskiej na frontach włoskim i rosyjskim. Po wojnie działał na rzecz przyłączenia do Polski Spisza i Orawy, w związku z tym w 1919 brał udział w Konferencji Pokojowej w Paryżu. Uzyskawszy stypendium Ministerstwa Wyznań Religijnych i Oświecenia Publicznego, w 1. 1922-1924 studiował w Instytucie Katolickim w Paryżu. Był kapelanem Zakładu św. Kazimierza, w 1. 1923-1924 redagował „Polaka we Francji”. Zaangażował się w działalność duszpasterską wśród polskiej emigracji zarobkowej, zwłaszcza wśród robotników rolnych. Po powrocie do Polski został redaktorem „Dzwonu Niedzielnego” (1924-1929) oraz sekretarzem Ligi Katolickiej. Przez trzy lata (1930-1933) był wikariuszem w katedrze wawelskiej, a następnie spowiednikiem przy kościele Mariackim (1933-1937). Od 6 grudnia 1937 do 23 października 1944 był proboszczem w parafii Najświętszego Salwatora na Zwierzyńcu z siedzibą w klasztorze Sióstr Norbertanek w Krakowie. 23 listopada 1938 został mianowany przez prezydenta Mościckiego senatorem Rzeczypospolitej. W 1944 został administratorem parafii mariackiej, później dziekanem m. Krakowa. Zmarł 31 lipca 1967 w Krakowie. Czy wiesz kto to jest?, red. S. Łoza, Warszawa 1938, s. 450. Materiaty, z. I, s. 65-67; P.W. Mynarz SOCis, Społeczna działalność ks. Ferdynanda Machaya wśród polskiej emigracji zarobkowej we Francji (1922-1924), „Studia Polonijne” 1(1976), s. 85-102; TENŻE, Działalność duszpastersko-społeczna ks. Ferdynanda Machaya, „Roczniki Teologiczno-Kanoniczne” 22(1975) z. 6, s. 85-95; S. GaJewski, Machay Ferdynand, w: Stownik biograficzny katolicyzmu społecznego w Polsce, t. II: K-P, Lublin 1994, s. 104-105; Posłowie i senatorowie Rzeczypospolitej Polskiej 1919-1939. Stownik biograficzny, t. IV: P-R, oprac. P. Majewski, red. G. Mazur, Warszawa 2009, s. 39-40.

${ }^{16}$ SzCZEPAn MisiaK - kapłan archidiecezji gnieźnieńskiej. Urodził się 25 grudnia 1894 w Grodzisku nad Prosną. Od 1910 naukę pobierał w Collegium Marianum Księży Pallotynów w Wadowicach, a od 1914 w gimnazjum w Niemczech. W 1916 został powołany do służby wojskowej, do 1918 przebywał na froncie francuskim. Początkowo, przez trzy lata studiował teologię na uniwersytecie w Monasterze, a następnie w Arcybiskupim Seminarium Duchownym w Gnieźnie. Święcenia kapłańskie przyjął 17 grudnia 1922 z rąk kard. E. Dalbora. Od 1 stycznia 1923 przez pół roku pełnił obowiązki duszpasterskie przy kościele farnym w Bydgoszczy. Latem 1923 podjął je wśród rodaków we Francji. Początkowo, od 1 lipca 1923 do 1926 w Merlebach (Moselle), następnie dojeżdżał do Freyming (Moselle), później, od 1 lipca do 27 września 1926 do Rosieres (Cher). W Waziers (Nord) pracował od 1 marca 1928 do 1 października 1931, następnie został przeniesiony do Nilvange Knutange (Moselle), do 15 października 1936. 17 maja 1932 został sekretarzem okręgowym Związku Stowarzyszeń Dzieci Polskich na dekanaty wschodniej Francji. Po powrocie do kraju pracował jako kapelan w więzieniu i dyrektor Caritasu w Inowrocławiu. 2 listopada 1939 został aresztowany i uwięziony w Inowrocławiu, od 5 listopada w Świeciu, od 8 listopada w Górnej Grupie, od 5 lutego 1940 w Gdańsku, od 8 lutego w Stutthofie, od 10 kwietnia w Sachsenchausen, od 14 grudnia 1940 w Dachau (nr obozowy 22 609). Z obozu został zwolniony 16 marca 1943. Po zakończeniu 
Suszyński $^{19}$, [Jan] Szydłowski ${ }^{20}$, [Ignacy] Śledziowski ${ }^{21}$.

działań wojennych administrował parafią św. Jakuba i parafią św. Jana Ap. w Mogilnie, gdzie od 1948 był proboszczem. W 1960 został przeniesiony do Nakła nad Notecią. Tam zmarł 1 grudnia 1963. Materiaty, z. III, s. 79-80; Materiały, z. XVIII, s. 66; Wspomnienie pośmiertne o śp. ks. Szczepanie Misiaku, „Wiadomości Archidiecezji Gnieźnieńskiej” 19(1964), nr 3-4, s. 69-70; ks. J. SzYMaŃski, „Nie chcemy tego ukrywać” - oczami świadków. Sytuacja duszpasterstwa polonijnego w Pótnocnej Francji w 1928 r., „Archiwa Biblioteki i Muzea Kościelne” 98(2012), s. 413-414.

17 JAN SADOwSKI - kapłan diecezji płockiej; od 2 stycznia 1922 diecezji Cambrai. Urodził się 24 czerwca 1889 w Cywinach na Ukrainie. We Francji przebywał od września 1908. Gimnazjum ukończył w Poitiers, a studia teologiczne w Paryżu. Święcenia kapłańskie przyjął w Paryżu 29 lipca 1921. Od 2 stycznia 1922 pełnił posługę duszpasterską wśród rodaków w: Valenciennes (Nord), od 30 grudnia 1940 w Bourg d'Oisans (Isere), skąd 30 grudnia 1944 powrócił do Valenciennes. Dojeżdżał do (16) polskich kolonii. W rejonie Valenciennes zamieszkiwało 28.000 Polaków. Zmarł 29 grudnia 1950 w Valenciennes. Materiały, z. I, s. 101; J. SzYMaŃSKI, „Nie chcemy tego ukrywać” - oczami świadków, s. 413.

18 Antoni Servignat - kapłan diecezji kamienieckiej. Urodził się 17 kwietnia 1873 w Żytomierzu. Święcenia kapłańskie przyjął 25 czerwca 1899. Posługę duszpasterską wśród wychodźstwa polskiego we Francji rozpoczął 22 marca 1923 w Lallaing (Nord), skąd 1 sierpnia 1925 został przeniesiony do Calanne Lievin. 1 sierpnia 1934 z uwagi na podeszły wiek został zwolniony z posługi duszpasterskiej. W 1941 był kapelanem szpitala w Gostyniu Wielkopolskim. Tamże, 6 października 1941 został aresztowany przez Niemców. Od 30 października 1941 przebywał w Dachau (nr obozowy 28085). Wywieziony na śmierć w transporcie inwalidów 28 maja 1942. J. SzymaŃski, ,Nie chcemy tego ukrywać” - oczami świadków, s. 367-377; Materiaty, z. IV-II/II: Księża polscy w duszpasterstwie Pótnocnej Francji 1922-1929, oprac. O.B. Panek OC, Paris 1992, s. 122-124.

${ }^{19}$ WŁADYSŁAW SusZYŃSKI - kapłan archidiecezji wileńskiej. Urodził się 22 stycznia 1898 w Janowie, k. Sokółki. Do szkoły uczęszczał w: Janowie, Sokółce i Grodnie. W 1916 wstąpił do Seminarium Duchownego w Wilnie. Święcenia kapłańskie z rąk biskupa J. Matulewicza przyjął 25 maja 1921. Kontynuował następnie studia specjalistyczne w Lublinie i Paryżu. Do Francji przybył 1 listopada 1922. Studiował w Instytucie Katolickim w Paryżu. Był duszpasterzem w: Abscon, Auberchicourt, Auby, Flers-En-Escrebieux, Paris, Villers-Saint-Paul. Po powrocie został administratorem parafii Jazno na Wileńszczyźnie i profesorem Seminarium Duchownego w Wilnie. W 1. 1942-1943 był więziony. Po zakończeniu II wojny światowej organizował przeniesienie seminarium duchownego z Wilna do Białegostoku. 19 stycznia 1948 został biskupem tytularnym Tabbory i sufraganem w Białymstoku. Pełnił funkcję rektora seminarium w latach 1946-1968, wikariusza generalnego archidiecezji w 1955 i 1968. 6 lipca 1968 został administratorem apostolskim polskiej części archidiecezji wileńskiej z siedzibą w Białymstoku. Zmarł 27 października 1968 w Warszawie. Materiały, z. I, s. 109.

20 JAN SZYDŁOWSKI - kapłan diecezji płockiej. Urodził się 7 lutego 1892 w majątku Staw k. Gąbina. Święcenia kapłańskie przyjął 27 czerwca 1915 z rąk bpa A. Nowowiejskiego. Czasowo pełnił obowiązki wikariusza w Gąbinie. W 1915 podjął studia we Fryburgu Szwajcarskim. We Francji pełnił posługę duszpasterską w: Betz, Guiscard, La Bouble, Lyon, Messeix, Nanteuil, Rethondes, Ricamarie, Ronchamp, Vaumoise, Villetretre. Powrócił do Polski w 1924. Był profesorem w seminarium płockim. 18 lutego 1941 został aresztowany przez Niemców. Zmarł w obozie w Działdowie 26 sierpnia 1941. Ks. M.M. GrZYBowski, Duchowieństwo diecezji płockiej. Wiek XX, t. I, cz.1, Płock 2007, s. 529-532.

${ }^{21}$ IGNACY ŚLEDZIOwSKI - kapłan archidiecezji lwowskiej. Urodził się 25 lipca 1866 w Chrościu (Staniątki). Święcenia kapłańskie przyjął 7 czerwca 1896. Posługę duszpasterską wśród wychodźstwa polskiego we Francji pełnił od 23 lutego 1921 w: Amiens, Argenteuil, Bonne-Fontaine par Rouge, 
Ks. rektor Szymbor zagaja zebranie, zaznacza, że wielu z zaproszonych nie mogło przybyć na zebranie. Porządek obrad przyjęto bez dyskusji.

Odczytano protokó ${ }^{22} \mathrm{z}$ ostatniego zebrania, który przyjęto; ks. Rektor wyjaśnił, że w udzielaniu listownych zawiadomień o zebraniu kieruje się ostrożnością ze względu na ważność i ścisłość naszych obrad.

Następnie ks. rektor Szymbor wygłosił obszerny referat o potrzebie założenia tygodnika katolickiego dla wychodztwa polskiego ${ }^{23}$, oraz potrzebie zrzeszenia polskich stowarzyszeń katolickich we Francji.

Referent, w sposób rzeczowy, wskazał przyczyny zniewalające nas do tej pracy, a mianowicie zaznajomił obecnych $\mathrm{z}$ akcją komunistyczną wśród robotników we Francji, z celem i metodami, jakimi się ona posługuje w wywieraniu wpływu na naszych wychodźców.

Następnie na podstawie obszernej korespondencji E. Kard. Dalbora, wykazał ks. Rektor, że Episkopat polski sprawą tą żywo się interesuje zarówno na swych zjazdach, jak też na specjalnych konferencjach, odbytych z udziałem czynników ustawodawczych; w tym celu miał przyjechać do Francji ks. patron Adamski. W szczególności zależy Biskupom naszym, by wychodźcy nie byli pozbawieni opieki duszpasterskiej a dzieci ich także i szkolnej, by łączyli się w katolickich organizacjach stanowych. Nadto Episkopat nasz uważa za niezbędne zrzeszenie tych stowarzyszeń pod hasłem wybitnie katolickim, w celu pielęgnowania życia narodowego, pomocy społecznej, porady prawnej, w celu utworzenia funduszu dodatkowego, obok pieniędzy łożonych przez dyrekcje kopalń i fabryk, na cele szkolnictwa i duszpasterstwa, na utworzenie księgarni katolickiej w Paryżu. W szczególności Episkopat

Calonne-Ricouart, Coueron, Evaux-Les-Bains, Marles-Les-Mines, Montmorillonn, Noeux-Les-Mines, Senots (Blequencourt-Senots). Archiwum Polskiej Misji Katolickiej we Francji. P. Personalia. P. IV. Ankieta personalna księży pracujących w ośrodkach duszpasterskich PMK w 1943; Materiaty, z. IV-II/II, s. 127-130.

${ }^{22}$ M. Brudzisz, Pierwsze zebranie księży, s. 141-154.

23 „Polak we Francji” - ukazywał się w nakładzie około 4 tysięcy egzemplarzy. Był urozmaicony tematycznie. Stałym elementem religijnym była zamieszczona w nim w każdą niedzielę Ewangelia i komentarz do niej. Dział „Życie i troski wychodźców” zawierał informacje o różnego rodzaju problemach wychodźstwa (górników, robotników rolnych itp.) w różnych częściach Francji, o życiu organizacyjnym wychodźstwa, szkolnictwie polskim i działalności kulturalnej. Pismo zawierało także różne wiadomości z Polski, ze świata i z życia Kościoła. Ważną rubryką był dział informacyjny dotyczący wynagrodzeń i ubezpieczeń, zawierający porady prawne, adresy instytucji społecznych zajmujących się pomocą emigrantom itp. W dziale rozrywkowym drukowano popularne nowele i powieści. Zamieszczane ilustracje dotyczyły w większości życia emigrantów. Przez cały czas ukazywania się służył duszpasterstwu objazdowemu informując o terminach i trasach przejazdu duszpasterzy polskich. Patronował także różnym inicjatywom samopomocy społecznej na emigracji, np. składki na utrzymanie Zakładu św. Kazimierza, na oświatę polską, staranie o szkoły polskie itp. Liczne listy do redakcji ukazujące dramatyczną niekiedy sytuację religijną, moralną i materialną emigrantów świadczą, że pismo rozchodziło się na terenie całej Francji i trafiało także do Belgii. Cyt. za: ks. J. SzYMAŃSKI, Rola polonijnej prasy katolickiej we Francji w okresie międzywojennym $w$ zachowaniu i obronie narodowych i religijnych wartości wychodźstwa polskiego na przykladzie „Polaka we Francji”, w: Czasopisma archiwów, bibliotek i muzeów Kościoła katolickiego, red. W.W. Żurek, Lublin 2014, s. 300. 
polski uważa obecnie za najpilniejszą potrzebę wydawania pisma katolickiego, będącego łącznikiem stowarzyszeń katolickich we Francji i zastępującego duszpasterza tam, gdzie go brak. Episkopat pragnie, by cała ta akcja była prowadzona pod kierownictwem Misji Polskiej Kat., która miałaby być centrum katolickich organizacji oświatowo- kulturalnych.

Potrzebę tę - mówił dalej referent - odczuwaliśmy już dawno, ale brakowało nam środków moralnych i materialnych: przed półtora rokiem było w Francji zaledwie paru księży polskich, dzisiaj jest ich 49-ciu. Podobnie znacznie powiększyła się liczba polskiego nauczycielstwa, jakoteż sióstr i pielęgniarek. Wychodztwo polskie we Francji dosięgło obecnie cyfry 310 tysięcy i już zgłoszono do Misji Polskiej 110 stowarzyszeń katolickich. Nadto 2/3 funduszu zakładowego na pismo mamy już zapewnione. Mówca naszkicował plan organizacji życia stowarzyszeniowego i wydawnictwa pisma.

Plan redakcyjny przedstawił szczegółowo ks. Machay w drugim referacie ${ }^{24}$.

Ks. Machay wyobraża sobie pismo, jako przede wszystkim religijne, a więc na pierwszej stronie zamieszczać winnno Ewangelje, przypadającą na dane niedziele, oraz krótką homilje; potem artykuł treści naukowo-religijnej. Pismo winno przypominać wychodztwu aktualne dlań kwestie moralne jak (pijaństwo, dzikie małżeństwa), a także winno przypominać obowiązki narodowe, budząc patriotyzm. Wreszcie powinno poruszać rozmaite zagadnienia, interesujące bezpośrednio wychodztwo, np. przytaczać zdarzenia z życia św. Barbary (dla towarzystw górniczych) ${ }^{25}$, wyjaśniać niektóre zwyczaje francuskie. Pismo winno dbać o zamieszczenie licznej korespondencji zwłaszcza z życia stowarzyszeniowego; w odpowiedziach zaś redakcji udzielać porad prawnych i.t.p. Do urozmaicenia pisma posłużyłyby opowiadania humorystyczne.

Pismo to jednak nie ma poruszać kwestji politycznych, winno zadowolić się sumarycznem zestawieniem wydarzeń ostatniej doby. Również winno wdawania się w polemikę z innymi pismami. Pismo to będzie zmuszone jednak, poruszać bolączki materialne wychodztwa, przede wszystkiem jednak winno być stróżem moralności.

Referent wspomniał o trudnościach osobistych, jakie napotyka w prowadzeniu redakcji pisma ze względu na swe studja, prosi jednak i liczy na poparcie obecnych. Pierwszy numer ukaże się z początkiem grudnia ${ }^{26} \mathrm{i}$ cały ten miesiąc przeznaczony będzie na zyskiwanie prenumeratorów, gdyż następny numer ukaże się dopiero w 1-szą niedziele po N.-Roku i odtąd pismo będzie wychodzić regularnie co tydzień.

Obaj referenci sformułowali następujące wnioski:

1. Zebrani uznają potrzebę założenia pisma katolickiego i związku stowarzyszeń katolickich wśród wychodztwa polskiego we Francji, i to 2. we formie, przedstawionej przez referentów.

${ }^{24}$ Podczas pierwszego zebrania księży polskich pracujących we Francji 13 kwietnia 1923 ks. Ferdynand Machay wprost zwracał uwagę duszpasterzy, że ,potrzebne jest pismo periodyczne, które ksiądz mógłby z czystym sumieniem rozszerzać”. Zob. M. BRudzisz, Pierwsze zebranie księży, s. 141-154; J. Szymański, Rola polonijnej prasy katolickiej we Francji, s. 299.

25 Wielkie Święto górnicze. Święta Barbara, Patronka górników (4 grudnia), „Polak we Francji” 30 XI 1924, s. 2-4.

26 „Polak we Francji”. Pismo poświęcone sprawom religijnym, społecznym i ojczystym, Paryż, wydanie świąteczne 23 grudnia 1923, nr 1 . 
Nad tymi referatami i wnioskami rozwinęła się mowa i dyskusja.

Odnośnie do treści pis ma, kilku mówców prosi o zupełne jasne podanie cywilnych formalności ślubnych. Ks. Śledziowski pragnie, by w części moralnej pismo wystąpiło w obronie czystości przedślubnej; prosi też, by nie zapomniano artykułów, dotyczących bractw Św. Franciszka, oraz bractw różańcowych. Ks. Misiak ostrzega przed zbytnią surowością w tępieniu pijaństwa. Ks. Jakubisiak widzi potrzebę poruszania zagadnień społecznych i politycznych z punktu widzenia etyki katolickiej. Ks. prałat Taczak radzi formę gawędową w artykułach apologetycznych; nie powinno się być obojętnym na zło, jakie szerzą przewrotne pisma, ale należy szkodników nazwać po imieniu. Ks. prałat Trocki radzi, by ks. Rektor Misji Polskiej wydał polecenie pisma, którą by księża mogli odczytać z ambon; ks. Rektor zawiadamia, że zwrócił się już do J.E. Prymasa Polski z prośbą o napisanie naczelnego artykułu do pierwszego numeru pisma.

Odnośnie do strony admnistracyjnej pisma ks. Taczak, na podstawie doświadczenia w sprowadzaniu dla wychodztwa, „Przewodnika Katolickiego”, radzi wystarać się głównie o uzyskanie prenumerat pojedynczych i ułatwianie odnawiania prenumeraty przez załączanie do pisma czeków całkowicie wypełnionych. Niezależnie od tego należy postarać się o dobrze zorganizowany kolportaż, do tego niezbędnym jest, żeby ktoś objeżdżał kolonje polskie.

Kontroli rachunków podjął się p. Au, dyrektor filji paryskiej Banku Związku Społ. zar... Po dyskusji uchwalono podstawę finansową pisma oprzeć na spółce udziałowej; fundusz udziałowy należałoby uzupełnić udziałami 50- frankowemi, wypłaconemi przede wszystkim przez duchowieństwo, oraz przez towarzystwa katolickie, które na walnem zgromadzeniu będzie reprezentował patron, a więc ksiądz. Ks. Gieszczykiewicz podnosi potrzebę zyskania anonsów do pisma, oraz wystarania się o adresy robotników rolnych za pośrednictwem głównego biura 'C.A.R.D.”, gdyż wiadomości o rozmieszczeniu robotników rolnych, podawane Misji Polskiej przez duchowieństwo miejscowe i kurje biskupie, są nieścisłe i bardzo niekompletne.

Po dłuższej dyskusji, w której głównie zabierali głos: ks. prałat Taczak, ks. rektor Szymbor i ks. Janiewski, ustalono następujące wytyczne dla pracy stowarzyszeniowej. Uznano potrzebę tworzenia odrębnych organizacji dla każdego stanu.

Dla młodzieży męskiej w wieku szkolnym uznano za najodpowiedniejsze związki harcerskie, które pod względem moralnym wiele mogą oddziałać na młodzież przez, dobrze dla młodzieży dostosowane, prawo harcerskie, nadto przez krzewienie czystości myśli i ciała, oraz przez, niezmiernie potrzebom wychodztwa odpowiadający, zakaz picia alkoholu; przytem harcerstwo bardzo dba o wychowanie fizyczne co umożliwi wspólne ćwiczenia gimnastyczne wraz z sokołami, a później przygotuje młodzież do wstępowania do towarzystw sokolich, tak we Francji już rozpowszechnionych.

- Zebrani oświadczyli, że w tych jak i następnych uchwałach, kieruje się zasadą, że należy się, o ile możności zastosować do obecnego stanu rzeczy, liczyć się z warunkami miejscowemi i zaczętych już prac nie utrudniać, ani nie psuć.

- Młodzież francuska katolicka należy do harcerstwa, nadto dowództwo harcerstwa polskiego obiecało pomoc - ułatwi to zakładanie związków harcerskich. Jakkolwiek harcerstwo nie ma charakteru religijnego, przecież zebrani spodziewają się, że o ile duchowieństwo ujmie w swe ręce inicjatywę w tworzeniu związków harcerskich, potrafi nadać 
im charakter katolicki i pozyskać je do zjednoczenia stowarzyszeń katolickich. Można i należałoby wśród stowarzyszonych zyskiwać członków Żywego Różańca (sodalicje jako nadające się bardzo dla młodzieży inteligentnej, nie byłyby na wychodztwie wskazane). Podobnie dla dziewcząt $\mathrm{w}$ pierwszym rzędzie, na wzór znanych w Polsce, należy tworzyć stoważyszenia młodzieży żeńskiej. Można też dodatkowo dla dziewcząt pobożniejszych zakładać Stowarzyszenia Dzieci Maryji, Żywy Różaniec.

Niezależnie od towarzystw sokolich i kół śpiewaczych, również wśród wychodztwa bardzo rozpowszechnionych, które podobnie należałoby pozyskiwać do zjednoczenia stowarzyszeń katolickich, należy jednak, niezależnie od nich, tworzyć osobne stowarzyszenia oświatowo- kulturalne robotników katolickich; wśród górników będą się one łączyć pod wezwaniem św. Barbary, ich Patronki, w centrach fabrycznych zaś pod wezwaniem św. Józefa, lub św. Polskich.

Osobne wreszcie stowarzyszenia należy tworzyć dla matek chrześcijańskich. Również w tych dwu ostatnich grupach stowarzyszeń należy rozpowszechniać zrzeszenia czyste religijne, jak bractwa różańcowe, Bractwa św. Franciszka.

Przy tak szeroko zakreślonym planie, okazuje się niezbędnym założenie wzorcowo funkcjonującego sekretariatu jeneralnego, który by w pierwszym rzędzie zajął się opracowaniem odnośnych instrukcji, pośredniczył w zaspokajaniu innych potrzeb organizacyjnych, oraz postarał się o uzyskanie odnośnych władz do zakładania towarzystw kościelnych, gdyż staranie się o nie na własną rękę z osobna w każdej miejscowej kurji biskupiej, sprawiałby nie mało trudności. Na sekretarza generalnego upatrzono X. Misiaka. W zjednoczeniu stowarzyszeń katolickich, jakoteż istniejącym przy nim sekretariacie jeneralnym winny działać cztery sekcje, odpowiadające wspomnianym czterym typom stowarzyszeń (t.j. młodzieży męskiej - żeńskiej - robotników katolickich - matek chrześcijańskich). Nadto obok tej centrali, z siedzibą w Paryżu, winny być utworzone c e n trale okręgowe na wzór utworzonej już w Wschodniej Francji.

Wszyscy c z ło n k o w i e stowarzyszeń katolickich winni prenumerować tygodnik katolicki, z wyjątkiem jeżeli należą do jednej rodziny, gdyż pismo nasze, nie mogąc ograniczyć się do zajmowania się potrzebami jednego tylko stanu, będzie organem wszystkich stowarzyszeń katolickich wśród wychodźstwa - przeto niepraktycznem byłoby zobowiązywanie z osobna członków jednej i tej samej rodziny do prenumerowania kilku egzemplarzy pisma. Niemożliwem też jest podnoszenie składek członkowskich do takiej kwoty, by z nich pokrywano prenumeratę pisma dla każdego członka. Trzeba się liczyć z tem, że opłaty członkowskie w stowarzyszeniach katolickich są obecnie minimalne ( $30-50 \mathrm{ct}$;) na miesiąc); nagłe kilka krotne podwyższanie tych składek: albo nie dałby się przeprowadzić, albo też spowodowałoby ubytek większości członków. Obok prenumerat indywidualnych, do których nakłaniać się będzie wszystkich członków zarządów, do kolportażu pisma; również sprawnymi kolporterami będą thumacze, o ile są nam życzliwi.

W ostatnim punkcie porządku dziennego, a mianowicie wolny ch wniosków, omawiano sytuacje, jaka wytwarza się skutkiem tych poczynań. W szczególności omawiano stosunek nasz do innych pism, oraz innych stowarzyszeń oświatowych i politycznych. Po udzieleniu obszernych wyjaśnień przez ks. rektora Szymbora i ks. Machaya, obecni ustalili wspólne linje postępowania i, pod hasłem jednomyślnej i solidarnej pracy, zamknął ks. Rektor 3 1/2 godzinne obrady. 


\section{BIBLIOGRAFIA}

\section{Źródla}

Archiwum Archidiecezjalne w Gnieźnie, Archiwum Prymasa Polski, Akta Protektora Wychodźstwa Polskiego, Francja, Dział III/14a, Protokół z drugiego Zebrania Księży Polskich, pracujących wśród wychodźstwa polskiego we Francji, odbytego dnia 15 listopada 1923 w lokalu Misji Polskiej w Paryżu, k. 9.

Archiwum Polskiej Misji Katolickiej we Francji. G. III. 2. Zjazdy duszpasterskie, sympozja, kursy dokształcające, 1923-1956; G. III. 2. 1. Zjazdy duszpasterzy Misji. N-ry 1-11. Protokół z drugiego Zebrania Księży Polskich, pracujących wśród wychodźstwa polskiego we Francji, odbytego dnia 15 listopada 1923 w lokalu Misji Polskiej w Paryżu, k. 9.

Archiwum Polskiej Misji Katolickiej we Francji. P. Personalia. P. IV. Ankieta personalna księży pracujących w ośrodkach duszpasterskich PMK w 1943.

\section{Literatura}

BADURA P.J., Jakubisiak Augustyn (1884-1945), w: Słownik polskich teologów katolickich 1918-1981, t. V, red. ks. L. Grzebień SJ, Warszawa: ATK 1983.

Brudzisz M., Pierwsze zebranie księży Polskiej Misji Katolickiej we Francji, „Studia Polonijne" 33(2012).

Снамот M., Taczak T. (1878-1941), w: Słownik biograficzny katolicyzmu społecznego w Polsce, t. III: R-Ż, Lublin: TN KUL 1995.

Czy wiesz kto to jest?, red. S. Łoza, Warszawa: Główna Księgarnia Wojskowa 1938.

DzwONKOwski R., Życie religijne Polonii francuskiej w latach 1920-1986 jako wyraz więzi z krajem pochodzenia, „Studia Polonijne” 15(1993).

Emigracja polska we Francji zagrożona, „Polak we Francji” 23 XI 1924, s. 9.

GAJEwski S., Machay Ferdynand, w: Słownik biograficzny katolicyzmu społecznego w Polsce, t. II: K-P, Lublin: TN KUL 1994.

GrzYbowski M., ks., Duchowieństwo diecezji płockiej. Wiek XX, t. I, cz. 1, Płock: Kronos 2007.

Klechta J., Najstarsza w świecie. Polska Misja Katolicka we Francji 1836-2006, Paryż 2006.

Kujawski W., ks., Sufragani włocławscy w XX wieku, w: W Panu złożyłem nadzieję. Księga pamiątkowa ku czci Bpa Czesława Lewandowskiego w 80. rocznicę urodzin, Włocławek: Włocławskie Wydawnictwo Diecezjalne 2002.

ŁubIEŃski H., Przed Zjazdem Duchowieństwa polskiego w Paryżu, „Polak we Francji” 14 XII 1924, s. 2.

Materiały do dziejów Polskiej Misji Katolickiej we Francji, z. I: Księża polscy w duszpasterstwie okręgu paryskiego 1922-1929, oprac. O.B. Panek OC, Paris: Editions François Dominique 1992.

Materiały do dziejów Polskiej Misji Katolickiej we Francji, z. II: Księża polscy w duszpasterstwie południowej Francji 1922-1929, oprac. O.B. Panek OC, Paris: Editions François Dominique 1993. 
Materiały do dziejów Polskiej Misji Katolickiej we Francji, z. III: Księża polscy w duszpasterstwie Dekanatu Wschodniego 1922-1929, oprac. O.B. Panek OC, Paris: Editions François Dominique 1992.

Materiały do dziejów Polskiej Misji Katolickiej we Francji, z. IV-II/II: Księża polscy w duszpasterstwie Północnej Francji 1922-1929, oprac. O.B. Panek OC, Paris: Editions François Dominique 1992.

Misjonarze św. Wincentego a Paulo w Polsce (1651-2001), t. II-1: Biografie, red. tomu II J. Dukała CM, Kraków: WITKM 2001.

Mynarz P.W. SOCist, Działalność duszpastersko-społeczna ks. Ferdynanda Machaya, „Roczniki Teologiczno-Kanoniczne” 22(1975), z. 6.

Mynarz P.W. SOCist, Społeczna działalność ks. Ferdynanda Machaya wśród polskiej emigracji zarobkowej we Francji (1922-1924), „Studia Polonijne” 1(1976).

Posłowie i senatorowie Rzeczypospolitej Polskiej 1919-1939. Słownik biograficzny, t. IV: P-R, oprac. P. Majewski, red. G. Mazur, Warszawa: Wydawnictwo Sejmowe 2009.

PonTY J., Les aumoniers polonais en milieu ouvrier immigre dans la France de l'entre deux guerres, w: Les contacts religieux franco-polonais du moyen age a nos jours. Relations, influences, images d'un pays vu par l'autre. Colloque international organisé par le C.N.R.S., GRECO nr 2. Histoire religieuse moderne et contemporaine et le Centre Interdiscipinaire d'Etudes des Religions de l'Université de Lille III. Lille 5-7 octobre 1981, Paris 1985.

SzYmański J., ks., Duszpasterze Polonii i Polaków za granicą. Słownik biograficzny, t. I, Lublin: Miejska i Powiatowa Biblioteka Publiczna 2010.

SzYMAŃski J., ks., Duszpasterze Polonii i Polaków za granicą. Słownik biograficzny, t. II, Lublin: Miejska i Powiatowa Biblioteka Publiczna 2011.

SZYMAŃski J., ks., „Nie chcemy tego ukrywać” - oczami świadków. Sytuacja duszpasterstwa polonijnego w Północnej Francji w 1928 r., ,Archiwa Biblioteki i Muzea Kościelne" 98(2012).

SZYMAŃSKI J., ks., Rola polonijnej prasy katolickiej we Francji w okresie międzywojennym w zachowaniu i obronie narodowych i religijnych wartości wychodźstwa polskiego na przykładzie „Polaka we Francji”, w: Czasopisma archiwów, bibliotek i muzeów Kościoła katolickiego, red. W.W. Żurek, Lublin: Wydawnictwo KUL 2014.

WolNiEWICZ M., ks., Taczak T., w: Słownik polskich teologów katolickich 1918-1981, red. ks. L. Grzebień SJ, t. VII, Warszawa: ATK 1983.

Wspomnienie pośmiertne o śp. ks. Szczepanie Misiaku, „Wiadomości Archidiecezji Gnieźnieńskiej” 19(1964), nr 3-4. 


\section{DRUGIE ZEBRANIE KSIĘŻY POLSKIEJ MISJI KATOLICKIEJ WE FRANCJI}

\section{Streszczenie}

Największą możliwość zamanifestowania więzi z ojczyzną przez naszych rodaków stwarzała struktura organizacyjna polskiej opieki religijnej, tzn. sieć stałych i dojazdowych placówek duszpasterskich. Dzięki współpracy Episkopatu Polski i Francji, związku pracodawców francuskich w głównych skupiskach emigrantów polskich powstała trwała struktura duszpasterstwa polskiego. 13 maja 1922 roku powołano do życia Misję Polską Katolicką we Francji. Od samego początku duszpasterze polscy wywierali zasadniczy wpływ na organizowanie się wychodźstwa polskiego. Opierając się na utworzonych ośrodkach duszpasterskich, kapłani podjęli posługę duszpasterską wśród rodaków, inspirowali lokalne polskie stowarzyszenia do obrony społecznych interesów emigracji i umacniania polskości. Wszystkim tym wyzwaniom usiłowała sprostać PMK pod kierownictwem ks. rektora Wilhelma Szymbora. Skalę tych wyzwań egzemplifikuje m.in. dokument: Protokół z drugiego Zebrania Księży Polskich pracujących wśród wychodźstwa polskiego we Francji, odbytego dnia 15 listopada 1923 w lokalu Misji Polskiej w Paryżu. Kopia dokumentu znajduje się w Archiwum Polskiej Misji Katolickiej we Francji. Natomiast dokument oryginalny w formie maszynopisu przechowywany jest w Archiwum Archidiecezjalnym w Gnieźnie.

Słowa kluczowe: Polska Misja Katolicka we Francji; duszpasterze polonijni; „Polak we Francji”

\section{THE SECOND MEETING OF THE PRIESTS OF THE POLISH CATHOLIC MISSION IN FRANCE}

\section{Sum mary}

The best opportunity to manifest the bonds with the homeland by our compatriots was provided by the organizational structure of Polish religious care, that is, a network of permanent and temporary pastoral centers. Thanks to the cooperation of the Episcopate in Poland and France, and the association of French employers in the main Polish immigrant communities, a permanent structure of Polish pastoral ministry was established. On May 13, 1922, the Mission of Catholic Poland in France was founded. From the very beginning Polish priests had a fundamental influence on the organization of Poles in exile. Based on the established pastoral centers, the priests ministered among their countrymen, inspired local Polish associations to defend the social interests of emigrants and strengthen Polishness. All these challenges were attempted by the Polish Catholic Mission under the guidance of Rector Wilhelm Szymbor. The scale of these challenges is exemplified by, among others, the following document: Minutes of the Second Meeting of Polish Fathers, working among Polish emigrants in France, held on November 15, 1923 at the premises 
of the Polish Mission in Paris. A copy of the document can be found in the Archive of the Polish Catholic Mission in France. The original document in the form of typescript is stored in the Archdiocesan Archives in Gniezno.

Key words: Polish Catholic Mission in France; Polish priests; "Pole in France"

Translated by Karolina Jurak 